\title{
Urgences
}

\section{À l'aurore...}

\section{Louise Beauchamp}

Numéro 13, mars 1986

\section{Éclats d'atelier}

URI : https://id.erudit.org/iderudit/025225ar

DOI : https://doi.org/10.7202/025225ar

Aller au sommaire du numéro

\section{Éditeur(s)}

Urgences

\section{ISSN}

0226-9554 (imprimé)

1927-3924 (numérique)

Découvrir la revue

Citer ce document

Beauchamp, L. (1986). À l'aurore... Urgences, (13), 57-58.

https://doi.org/10.7202/025225ar

Ce document est protégé par la loi sur le droit d'auteur. L'utilisation des services d'Érudit (y compris la reproduction) est assujettie à sa politique d'utilisation que vous pouvez consulter en ligne.

https://apropos.erudit.org/fr/usagers/politique-dutilisation/
Cet article est diffusé et préservé par Érudit.

Érudit est un consortium interuniversitaire sans but lucratif composé de l'Université de Montréal, l'Université Laval et l'Université du Québec à Montréal. Il a pour mission la promotion et la valorisation de la recherche. https://www.erudit.org/fr/ 


\section{Louise Beauchamp}

À l'aurore ce mur, dans le noir. Très tard, ce mur derrière cette femme nue, flamboyante, étendue sur un lit de coton bleu royal, bordé de fleurs gentiane. Couleurs océanes, langueurs essouflantes sous cette chaleur torride.

Des papiers noircis. De l'autre côté, autre univers clos. Intime. Marquis de Sade et autres, sad sad life. Emma, Virginia, Marguerite: femmes aimées, amantes douces. Pourtant, près d'elles, une table de bois. Cela dépend, bien sûr, du point de vue où l'on se place. Seule. Monde de papier d'outre-ailleurs. Des monstres, quelques nuits, traversent le mur dans ses pores d'acrylique blanc cerise.

Alors là, et seulement là, l'usage normal du tableau hésite. Elle ouvre ses yeux un peu plus grand, de petits plis, comme des rayons, se forment à la commissure des paupières. Peau mûre: petits trous microscopiques, couleur feu, respirant d'aise, cils de peau oscillant de chaleur et de calme. Un jour pourra-t-elle se lever? On parle dans son dos, quelle indiscrétion! Un corbeau, ressemblant étrangement au voyeurvigilant, est perché sur le bord de la fenêtre, aux volets entrouverts, ce ne sont que des yeux de plus sur elie. Impassible.

Un bruit régulier, tel le son d'un marteau tenace sur l'acier, m'attire. Je la quitte. On m'appelle de l'autre côté de ce mur. Il faudrait bien que je rédige quelques pages essentielles. Mes yeux ne le traversent point. Une masse oranger, sans forme, s'accroche à lui, épousant sa surface mais non sa matière. Quelles épousailles pourtant ils feraient!

Soyons chastes et pures, hésitons avant de retourner nous allonger près de cette femme nue, sans colliers ni faux sortilèges. "Thank you Satan" pour mes marquises-états... 
Ondoyances nocturnes. Nulles peines, lune pleine, nuls maux sans croix ni bois au-dessus. Mille frôlements, cent contenances, près d'elle. Impassible. NEVERMORE, c'est écrit. Elle le sait pourtant, NEVERMORE. Tout près d'elle, il y a le vieil appareil à musique et son cornet gros comme un tuba, entourés de fleurs et de bleus noyés. Mais de son, aucun. C'est heureux ainsi, puisque cela fait tant d'années qu'elle tente de s'endormir sous l'oeil du voyeur-vigilant, moi, par le fait même, je la mets en abîme.

C'est à n'y rien comprendre; je ne vois pas à travers les murs. Ce mur ennuit de noir, en ce minuit lugubre de ma chambre, le livre de Poe à mon chevet comme sursis au chagrin. Quelle étrange position dans mon logis par erreur hanté. Mon corps ne s'emportera jamais plus. C'est le corbeau en mes secrètes oreilles qui me crie "Jamais plus".

Paul, intendance supérieure des mouvements minimaux, elle ne pourra donc jamais se lever et m'atteindre en cette chambre déserte et désolée?

De l'autre côté, étant donné CE mur, je n'imagine plus rien. 